\section{Solid og lett tilgjengelig om gastrointestinal patologi}

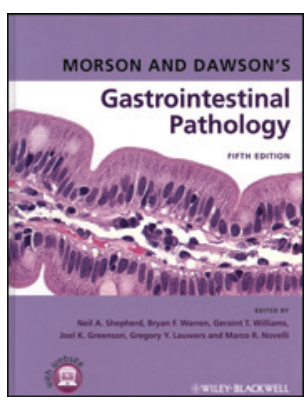

Neil A. Shepherd, Bryan F. Warren,

Geraint T. Williams et al, red.

Morson and Dawson's gastrointestinal

pathology

5. utg. 873 s, tab, ill. Chichester:

Wiley-Blackwell, 2013. Pris GBP 170

ISBN 978-1-4051-9943-8

Siden Morson and Dawson 's gastrointestinal pathology ble utgitt for første gang i 1972, har det vært en betydelig utvikling innen gastrointestinal patologi. Etter hvert som nye unders $ø$ kelsesmetoder og behandlingsprinsipper tas i bruk, stilles det nye krav til den histopatologiske undersøkelsen av vevet. Selv om morfologi sett i HE-fargede snitt fortsatt er basis i patologisk diagnostikk, gjøres immunhistokjemiske undersøkelser og etter hvert molekylære analyser i økende grad.

Som tidligere utgaver er denne nye utgaven en solid og omfattende bok innen gastrointestinal patologi. Teksten er lett tilgjengelig, illustrasjonene er gode, og stikkordregisteret er brukervennlig. Forfattere fra ulike deler av verden skriver om sine spesialfelt, noe som gjør boken mer internasjonal enn tidligere utgaver.

De sju hoveddelene er inndelt i øsofagitt, ventrikkel, tynntarm, appendiks, tykktarm, analregion og peritoneum. Hver del starter med normal anatomi og histologi, fulgt av embryologi og utviklingsforstyrrelser. I de følgende kapitlene beskriver forfatterne morfologi, patogenese og etiologi innen de ulike tilstandene, og de inkluderer også immunhistokjemi og molekylærpatologi.

Som ung assistentlege i patologi var dette en av de første fagspesifikke bøkene jeg lærte å kjenne, og hadde ubegrenset tillit til. Etter hvert har jeg skjønt at sannheter forandrer seg over tid, og eksperter, inkludert fagbokforfattere, kan ha ulik oppfatning, f.eks. om klassifiseringer. Dette gjelder også enkelte temaer i denne nye utgaven. Dersom man slår opp på «nevroendokrin tumor» i stikkordregisteret, står det: «se endokrin tumor». Siste utgave av WHO's classification of tumours of the digestive system (1) har kommet med en ny inndeling av nevroendokrine tumorer i gastrointestinaltraktus, og nevroendokrin tumor og nevroendokrint karsinom er innarbeidede begreper både blant klinikere og patologer. Jeg synes det hadde vært en fordel om boken hadde benyttet samme terminologi og klassifikasjon som WHO.

Samtlige utgaver har vært meget anerkjente bøker innen gastrointestinal patologi, og denne nye utgaven er ikke noe unntak. Dette er en nyttig og lett tilgjengelig lærebok for unge leger som skal lære seg patologifaget, og en god oppslagsbok for mer erfarne patologer med spesiell interesse for gastrointestinal patologi. Den bør derfor finnes på enhver patologiavdeling.

\section{Else Marit Løberg}

Overlege, Avdeling for patologi

Oslo universitetssykehus, Ullevål

\section{Litteratur}

1. Bosman FT, Carneiro F, Hruban RH et al. WHO Classification of tumours, volume 3. World Health Organization, 2010.

\section{Svært variabelt om sosial kognisjon}

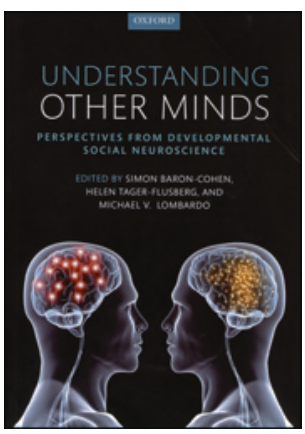

Simon Baron-Cohen, Michael Lombardo, Helen Tager-Flusberg, red. Understanding other minds

Perspectives from developmental social neuroscience. 3. utg. 498 s, tab, ill. Oxford: Oxford University Press, 2013. Pris GBP 40 ISBN 978-0-19-969297-2

Målet er å gi en oppdatering av det siste og det fremste innenfor forskningsfeltet på «theory of mind» og sosial kognisjon. Alle kapitler er skrevet av de fremste forskerne i feltet, og slik sett holder boken et meget høyt faglig nivå, men det fører samtidig til at det blir lite oversiktlig og vanskelig å lese.

Dette er en bok som er skrevet av forskere for forskere, og det er vanskelig å se for seg noen annen målgruppe. Noen av kapitlene er meget gode, men de fleste er tunge og forutsetter kunnskaper innenfor både forskning og nevrovitenskap.

Trass i at kapitlene omhandler veldig overlappende områder, har det ikke vært gjort noe arbeid for å koordinere skrivingen eller de mange forfatterne, slik at samme studier siteres gang på gang, i forskjellige sammenhenger. Nettopp mangelen på helhet og koordinering i dette sammensatte fagområdet gjør det frustrerende å lese boken fra A til $\AA$. Den fungerer dermed best som referansemateriale for den som ønsker å lære mer innenfor sosial kognisjon. Jeg anbefaler å lese de kapitlene som tar for seg de konkrete aspektene av «theory of mind» som man ønsker å lære mer om - uansett om dette er i forhold til utviklingspsykologi eller psykopati.

Boken fremstår som en antologi, og dermed er kvaliteten meget variabel, avhengig av forfatterne av det enkelte kapittel. Dessverre er første kapittel, Early manifestations of mindreading, nærmest uleselig, mens kapittel fem, Can theory of mind grow up?, og de to siste kapitlene, Mindreading by simulation: The roles of imagination and mirroring og Mindreading of the self er meget leseverdige og anbefales på det varmeste.

\section{Maj-Britt Posserud}

Postdoktor, Psykisk helsevern for barn og unge

Haukeland universitetssykehus 